\title{
Disposable Diapers Home-scale Composting Enhanced by Spirulina Platensis and Its Utilization As a Growing Medium for Maize and Cayenne Pepper
}

Diana Indah Kusumawati ( $\sim$ Diana.indah.k@gmail.com )

Institut Teknologi Sepuluh Nopember https://orcid.org/0000-0001-7620-3072

Sarwoko Mangkoedihardjo

Institut Teknologi Sepuluh Nopember

\section{Research}

Keywords: composting, disposable diapers, phytotoxicity tests, Spirulina platensis

Posted Date: May 5th, 2021

DOl: https://doi.org/10.21203/rs.3.rs-466350/v1

License: (a) (1) This work is licensed under a Creative Commons Attribution 4.0 International License.

Read Full License 
$2 \quad$ Spirulina platensis and its utilization as a growing medium for

$5 \quad{ }^{1}$ Department of Environmental Engineering, Faculty of Civil, Planning, and 
11 Disposable diaper waste harms the environment and human health. Composting has

12 gained attention for diaper waste recovery because of cost-effectiveness and wastes

13 conversion into value-added products. Cyanobacteria advantages over other

14 microorganisms to enhance the disposable diapers composting has studied. This

15 research aimed to determine the affection of Spirulina platensis, which is one of the

16 Cyanobacteria species, in the diapers composting. Given the complexity of separating

17 materials, the process involves all parts of disposable diapers. The reactor volume is

1830 litres, made of clear plastic to allow Spirulina absorbs light to carry out

19 photosynthesis. A total of $3 \mathrm{~kg}$ of disposable diapers composted together with $7 \mathrm{~kg}$ of

20 food waste, 250 grams of rice husks as a bulking agent, and pure culture of S.

21 platensis with various density: 1.5, 3.0, 6.0 million of sinusoids. All composting

22 reactors operated in triplicates. The parameters analyzed were organic Carbon, Total

23 Nitrogen, $\mathrm{C} / \mathrm{N}$ ratio, moisture content, $\mathrm{pH}$, and temperature. After a 6-week

24 composting process, compost with the 6.0 million sinusoids attained the highest

25 degradation rate and the total nitrogen $47 \%$ higher than the control. The final compost

26 had good quality and accomplished the limits set in the national regulation. It can be 
used as a growing medium, as shown in the phytotoxicity tests performed using maize and cayenne pepper. It is a feasible and affordable option for the valorization of disposable diapers, which can apply on a small or home-scale by the community.

30 Keywords: composting; disposable diapers; phytotoxicity tests; Spirulina platensis

\section{Introduction}

A kind of waste that cause the problem almost all over the world is disposable

34 diapers, which can be in baby diapers, sanitary napkins, personal care wipes, and

35 adult incontinence products. The use of disposable diapers is inevitable in human life

36 today. This product contributes to economic development and community welfare.

37 Also, better hygiene, skin protection, comfort and convenience in human life in

38 general. While this also poses significant problems for the environment compared to

39 cloth diapers in terms of resource consumption, increased waste generation,

40 environmental pollution, greater energy use, and harmful risk to human health from

41 its waste, many people still use disposable diapers (1). Disposable diaper waste

42 composition consists of $88 \%$ human excreta in the form of urine (74\%), followed by

43 faeces (14\%), then the diaper material itself (12\%) that is Cellulose, Super Absorbent 
44 Polymer (SAP), Polypropylene (PP), Low-Density Polyethylene (LDPE), and others

45 (2). The improper handling of diaper waste endangers the environment and human

46 health.

47 In almost all developing countries where the waste management system is

48 inadequate compared to waste generates, processing diaper waste easily at affordable

49 costs and providing direct benefits to people lives is meaningful. Composting is a

50 promising method to treat diaper waste for the following reasons. Composting

51 reduces organic waste with cost-effectiveness and wastes conversion into value-added

52 products, namely compost. Composting restoring valuable nutrients such as nitrogen

53 and phosphorus from human waste as the main components of organic fertilizers ( $\underline{3})$.

54 The application of fertilizers resulting from SAP recovery can increase water

55 retention in soil (4). In terms of LDPE and PP contain in diapers, degradation of

56 plastic by microbes is one of the eco-friendly and innovative methods even though no

57 protocol has developed yet to biodegrade polyethylene on a commercial scale (5).

58 Some research has studied disposable diapers composting. However, some issues

59 remain to address, such as a long time duration of 60-106 days. While the waste

60 generated every day, a long composting will require a large area of land. The 
61 pathogens, undecomposed plastic polymers, the lack of data about compost

62 application was also challenges in composting diapers. According to the prior study,

63 the advantages of diaper composting at home-scale and the possibility of

64 cyanobacteria utilization to enhance it has discovered (ㅁ). Enhanced composting

65 performance could mean better organic matter degradation, faster stability time ( $\underline{7})$,

66 and reduce nitrogen loss (ㅁ).

67 In this study, Spirulina platensis, as one of the cyanobacteria species, was chosen

68 as a microbial agent because of several advantages studied previously, in addition to

69 nitrogen fixation, such as: can live in a wide-range natural habitat, including in

70 aerobic composting conditions (9), proven utilization as a biocontrol agent because of

71 the higher phenol and polysaccharide concentrations compared to other cyanobacteria

72 strains ( $\underline{10})$, as inoculants (11), absorb DDT and possibly other organochlorine

73 pesticides (12), can grow and colonize on plastics which allows decomposing plastic

74 polymers, can remediate heavy metals and various other pollutants (13), increase

75 nutrients in the soil (14) because it has a very high content of macro and

76 micronutrients (such as essential amino acids, proteins, lipids, vitamins, minerals and

77 antioxidants), and easy to cultivate (15), those $S$. platensis abilities make them a 
78 significant microorganism for environmental and agricultural sustainability.

79 Co-composting considered a suitable method to face the problem in diapers

80 composting. Co-composting is composting more than one organic waste to give

81 advantages in the composting system (16). Food waste comprises the main fraction

$82(55 \%)$ of total municipal solid waste in developing countries. The environmental

83 impacts connect to food waste composting are emissions of greenhouse gases and

84 odours (17). Likewise, the disposal of agricultural wastes such as rice husk will

85 occupy huge lands and seriously threaten the environment because of the risk of

86 releasing nutrient, odorous and hazardous substances. However, from another view,

87 these wastes are valuable for soil erosion control and nutrient replenishment if

88 suitably treated before disposal (18). Disposable diapers co-composting with food

89 waste and agriculture waste is a potential way of dealing with waste generation. It

90 enables the production of compost with better quality while contributing to

91 sustainable waste management. Apart from the reasons for the diversity of

92 microorganisms, co-composting human excreta with food waste is rich in nutrients

$93(\underline{19})$.

94 So far, not many studies have reported on the diaper compost application. A few 
95 of them is for mushroom cultivation of Pleurotus ostreatus $(\underline{20}, \underline{21})$ and tomato plants

96 (22). What distinguishes this study from the previous ones is, all those three studies

97 used the diapers containing urine only. While this study involves all parts of the

98 diaper, include urine and faeces and an improving method through the S. platensis

99 addition to maximize the composting process. It cuts composting time and enriches

100 total nitrogen in the compost. There are no pathogenic bacteria detected in the

101 compost, even though faeces is one of the compost feedstock. As the main challenges

102 of using diapers containing human excreta in co-composting are the availability of

103 pathogenic microorganisms in the slurry. So, this research proved that no need to

104 worry about composting the diapers filled with faeces at home-scale, with simple

105 equipment, then using the compost in the food resources provision.

106 This research focus is to determine $S$. Platensis' effect in enhancing the

107 co-composting process. Also, to test the feasibility of compost resulted as a growing

108 medium. Following the different formulation of the medium from the compost, it

109 evaluated its performance in growing maize and cayenne pepper in the polybag. The

110 germination index observed as an evaluation of the utilization of the compost for

111 plant's growth. The findings of this study advocate the concept of recycling waste as a 
112 valuable resource. While simultaneously serves as a promising alternative to the

113 community concerning a healthy environment and income generation.

114

115 2. Materials and methods

116 The selection of composting additives, the equipment, and the operating

117 procedures must consider the aspects of cost and ease of implementation. Although

118 some additives, equipment and methods have proven to be successful in the

119 composting process, if they are expensive and complicated to operate, it will be hard

120 to apply by the community.

121

122 2.1. Materials

123 2.1.1.Composting process

124 The equipment used is knives to chop food waste; scissors to cut diaper waste;

125 wooden stirrers to stir trash; scales to measure the mass of equipment and materials;

126 Soil Tester to measure the temperature and $\mathrm{pH}$ of compost. Personal protective

127 equipment, such as masks, gloves are used as protection from pathogens exposure

128 when experimenting; 4 units of composting reactor as illustrated in Figure 1. 


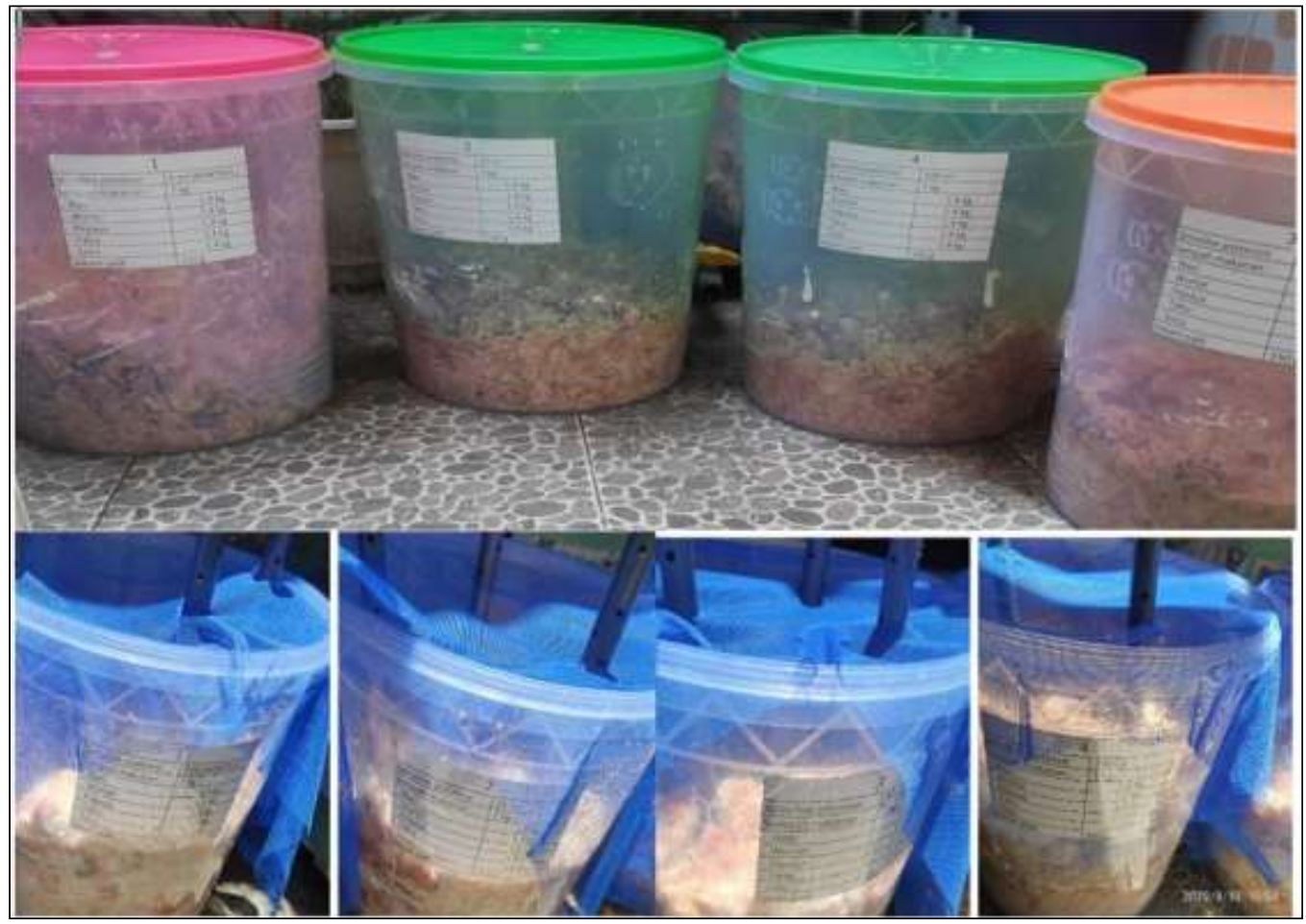

Fig. 1. Composting reactor with lid and aeration pipe

litres, made of thick and clear plastic to allow sunlight to enter because Spirulina

requires sunlight to carry out photosynthesis. The moisture content removed through

140 evaporation and leachate separation. For this reason, gauze is used for daily covering

141 to facilitate the water evaporation from the compost pile but still avoid disturbing

142 animals such as flies. The reactor also has a plastic lid so that composting applied in

143 open or closed systems. The reactor cover used when a rainy day. Four PVC pipes

144 with a diameter of $1 / 2$ " given holes along the pipe length, installed vertically in each

145 reactor. The purpose is to circulate air in the composting system. 
146 The raw material used is disposable baby diapers pants in various brands that

147 contain both urine and faeces. Disposable baby diapers obtained from several

148 households around the study site. And also from the Martopuro Waste Processing Site

149 in Pasuruan Regency. Diaper waste chopped using scissors with a size of $<5 \mathrm{~cm}$. All

150 parts of disposable diaper waste tested for composting.

151 The food waste consists of staple food, vegetables, fruit, side dishes and dairy

152 product, such as rice, carrot, papaya, tofu, and milk. Rice husks as bulking agent

153 obtained from rice fields in the Pasuruan Regency. Pure culture of S. platensis from

154 the Center for Brackish Water Cultivation Fisheries (Balai Besar Perikanan Budidaya

155 Air Payau or BBPBAP) in Jepara, Indonesia. The S. platensis cultivation in BBPBAP

156 carried out with the initial culture density $>10,000$ sinusoids $/ \mathrm{ml}$. The fertilizers used

157 are Urea (80 ppm), SP-36 (40 ppm), ZA (20 ppm), EDTA (5 ppm), $\mathrm{FeCl}_{3}(1 \mathrm{ppm})$ and

158 vitamin $\mathrm{B}_{12}(0.001 \mathrm{ppm})$. The culture process includes preparation of tools and

159 materials, fertilization and inoculation of seeds to culture treatment. The culture

160 medium prepared at a salinity of $15 \mathrm{ppt}$, and the incoming sunlight intensity was

161 around 3000 lux (12 hours light: 12 hours dark). The density of S. platensis used was

16260,000 sinusoids/ml in the exponential phase. 
163 The materials used in each composter are $3 \mathrm{~kg}$ disposable baby diapers, food

164 waste consisting of rice $(1,4 \mathrm{~kg})$, carrots $(1,4 \mathrm{~kg})$, tofu $(1,4 \mathrm{~kg})$, papaya $(1,4 \mathrm{~kg})$, milk

$165(1,4 \mathrm{~kg})$, and $250 \mathrm{~g}$ of rice husks. All the materials put into the reactors then stirred to

166 make them homogeneous. The concentrations of S. platensis added at the initial stage

167 as follows: $\mathrm{R} 1$ ( $0 \mathrm{ml}$, as control), $\mathrm{R} 2$ (25 $\mathrm{ml}$ or 1.5 million of sinusoids), R3 (50 ml or

1683 million of sinusoids), and R4 (100 $\mathrm{ml}$ or 6 million of sinusoids).

\subsubsection{Phytotoxicity test}

171 Relate to the compost application, phytotoxicity-test carried out on the maize and

172 cayenne pepper, kind of plants that people consume, and resistant to widespread

173 environmental conditions. Those plants had been used in several previous studies to

174 determine the effect of a pollutant on its growth. Some phytotoxicity testing

175 procedures require the representatives of two classes of flowering plants, which is

176 monocots and dicots (23). Cayenne pepper (Capsicum Frustescent L.) belongs to the

177 Solanaceae family and represents dicot plants. Meanwhile, maize (Zea mays L.) is

178 monocot plants and belongs to the Poaceae (Gramineae) family.

179 The preparation conducted independently by drying 20 maize kernels and 40 
cayenne pepper, then soaked in water for 12 hours. It is to provide sufficient moisture

181 and to determine the quality of the seed. This study only used the sunk ones. Other

182 materials and equipment are as follows: Ten pieces of polybag measuring $10 \times 20 \mathrm{~cm}$,

183 diaper compost from research results as much as $500 \mathrm{gr}$, and natural soil $500 \mathrm{gr}$.

184

\subsection{Methods}

\subsubsection{Composting process}

Research conducted in triplicates for 42 days in Pasuruan City, Indonesia. The

188 process held not in laboratory condition but the house situation (home composting)

189 with an in-vessel method by placing the composting reactor in the backyard. It is in a

190 place that allows sunlight to enter into the reactor with no additional lighting at night.

191 Light is a necessary growth factor for S. platensis, but lighting 24 hours a day not

recommended. During the dark period, chemical reactions such as protein synthesis and respiration occur (15). Composting conducted under aerobic conditions, in which aeration required to control the environment needed for the growth of the aerobic microbial community (24). Aeration was carried out manually by agitating the 
sufficient oxygen and evaporate excess moisture, resulting in a higher rate of evaporation, faster drying of compost, as well as cooling of compost, preventing excessive methane emissions. At the end of the composting period, the final density

200 of Spirulina was unmeasured.

201 Analysis of compost characteristics for moisture content using the Gravimetry

202 method, C-Organic using the Kurmies method, and Total N using the Kjeldahl

203 method carried out at the Laboratory of the Faculty of Public Health, Airlangga

204 University, Surabaya. While the analysis of Escherichia coli pathogens using the

205 MPN method at the Regional Health Laboratory of the Health Service Pasuruan

206 Regency. The $\mathrm{pH}$ and temperature observations used a soil tester by measuring at 3

207 points in $50 \%$ of the compost pile depth, which carried out every day (25). The

208 characteristics test analyzed at the initial stage, then periodically every 5-6 days. All

209 part of the highest degradation rate compost, not chopped, then tested for

210 phytotoxicity.

211

212

\subsubsection{Phytotoxicity test}

213 The phytotoxicity test carried out using the 'Direct growth test' method for 21 
214 days (26). Polybags filled with a growing medium made of compost and natural soil

215 with a total weight of 100 grams per polybag (P). The composition of natural soil and

216 compost are 100:0 (P1), 70:30 (P2), 50:50 (P3), 30:70 (P4), and 0;100 (P5). The sown

217 seeds densities on the growing medium in polybag are four maize kernels and eight

218 cayenne pepper seeds. Testing held by placing polybags unexposed to direct sunlight,

219 protected from rain and adding water if needed. The best composition of growing

220 medium for maize and cayenne pepper germination determine by observations and

221 calculations carried out on the parameter: Relative Seed Germination (RSG), while on

222 plant growth, root length is calculating to measure the Germination Index (GI) using

223 the formula:

224

225

- Seed Germinated (SG):

$226 \mathrm{SG}=\frac{\text { Number of normal sprouts }}{\text { Number of seeds planted }} \times 100 \%$

227 - Relative Seed Germination (RSG):

228

$\mathrm{RSG}=\frac{\mathrm{SG}_{\text {sample }}}{\mathrm{SG}_{\text {control }}} \times 100 \%$

- Relative Root Length (L)

$\mathrm{L}=\frac{\text { Average length of plant roots }_{\text {sample }}}{\text { Average length of plant roots }} \times 100 \%$ 
236 inoculation affected the composting. Also, the effect of the diapers compost in the

237 growing medium on germination and plant growth in the phytotoxicity test. Microsoft

238 Excel version 14.0.4734.1000 by the data analysis feature used for that purpose.

\section{Results and discussion}

\subsection{The characteristics of the compost material}

Table 1. From the first day to the third day, a mesophilic phase occurred with a

245 lasts between 25-40 ${ }^{\circ} \mathrm{C}$ for several hours to several days. In this phase,

246 microorganisms adapt to the environment and degrade simple compounds, such as

247 sugars, amino acids, and proteins. 
249 thermophilic phase (27), in R1, R3, R4. It happened just one day, and then the

250 temperature fluctuated and varied below $40{ }^{\circ} \mathrm{C}$, except at $\mathrm{R} 1$ that reached $42^{\circ} \mathrm{C}$ on

251 the 8th day. In the thermophilic phase, there is the degradation of organic matter

252 (polysaccharides, protein and fat) (28) and macromolecular compounds

253 (hemicellulose, cellulose, and lignin) $(\underline{16}, \underline{29})$. Pathogens and weed seed destruction

254 can effectively occur in this phase ( $\underline{30})$. The relatively short duration of the

255 thermophilic phase, caused by the inactivation of the microorganism and the higher

256 oxygen demand by aerobic microorganisms than supply oxygen (31). It can also

257 attribute to the amount of raw material used in the composting experiment that only

$25810 \mathrm{~kg}$ per reactor. The size of the small-scale composting reactors cannot generate

259 enough heat. In this condition, the compost pile temperature is almost the same or

260 adjusts to the ambient temperature.

261 Starts from the fifth day, the temperature fluctuated below $40{ }^{\circ} \mathrm{C}$. It is called

262 the cooling phase. For the last two days of composting, the heat in all reactors

263 recorded at $28-29^{\circ} \mathrm{C}$, which indicates that the compost has entered the maturation

264 phase. The cooling phase characterized by low microbial activity and slow biological 
265 processes associated with degradable organic substrates depletion. During this phase,

266 the mesophilic microorganisms adapt and reappear after being inactive in the

267 thermophilic phase and hydrolyzing the remaining cellulose and lignin material.

268 Humification of the organic matter and maturation occurs. The longer this phase lasts,

269 the greater the degree of humification ( $\underline{30})$. In this study, the average $\mathrm{pH}$ range of R2,

$270 \mathrm{R} 3$, and $\mathrm{R} 4$ were 5.58, 5.39 and 5.63. Relate to the low $\mathrm{pH}$, even though $\mathrm{pH} 9-11$ is

271 the optimum $\mathrm{pH}$ for Spirulina growth (15), these microorganisms can found in acidic

272 environments with $\mathrm{pH}$ values lower than 5-6 because cyanobacteria can adapt to

273 extreme stresses and environmental conditions quite well. However, it rarely

274 happened (10). The temperature and $\mathrm{pH}$ changes during composting shown in Figure

$275 \quad 2$.

276 Humidity is a critical factor in decomposing because microorganisms need

277 water to grow and carry out their activities (24). Composting material should not be

278 too wet because it reduces the degree of porosity as air space, forms water logs, limits

279 oxygen supply, and results in anaerobic fermentation. It stops the biological activity

280 of composting in the form of metabolism, movement and transportation of nutrients. 


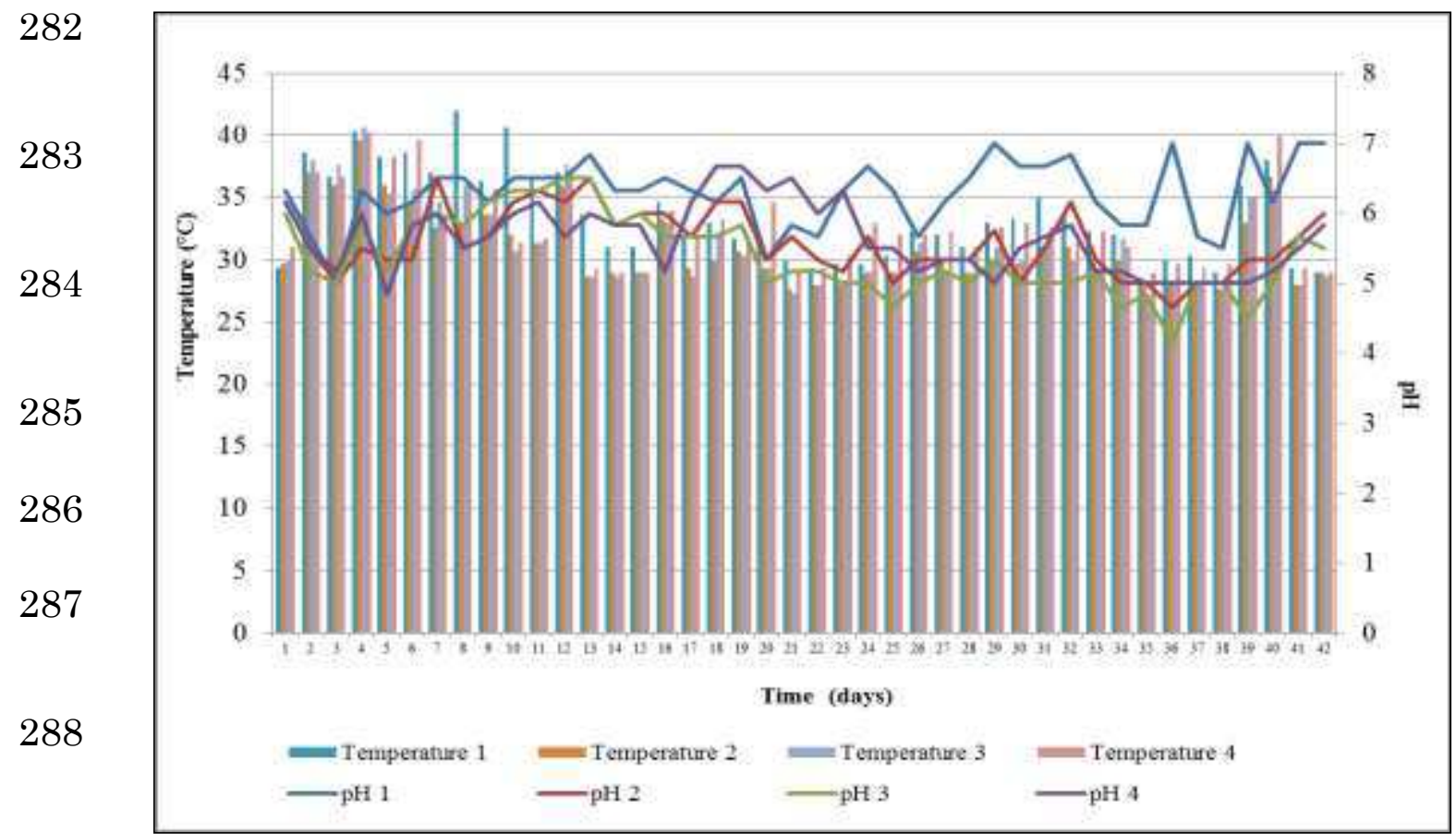

289

Fig. 2. Temperature and $\mathrm{pH}$ during composting

The composting system should also not be too dry since it slows down

291 microbial degradation. The optimum water content for biological activity during

292 composting is between 50 and $60 \%$ by weight of compost (29), but as an exception,

293 because there is cellulose in diaper waste, composting requires a higher water content

294 to soften fibrous materials such as lignocellulose (32). The moisture content at the

295 beginning of composting was 73.3 - 75\%. The high water content in all reactors

296 causes the movement of oxygen hampered because the compost pores are closed with

297 water so that the process becomes anaerobic and produces odours, which smells like

298 yeast at the beginning of the composting process. The water content at the final

299 compost decreased to $49.7-52.1 \%$, which indicates that the compost is mature and 
stable (33).

301 Pathogens originating from human waste can be a problem in composting (16).

302 Since pathogens from organic waste used as compost raw materials can pose health

303 risks to humans and animals by causing outbreaks transmitted through contaminated

304 compost (28). Therefore, it is necessary to minimize this pathogenic problem because

305 the compost produced is expected to be rich in nutrients, biologically stable, free from

306 pathogens and weed seeds, thus can be used as a soil improvement material without

307 any restrictions. At the beginning of the study, E. coli detected in all reactors with

308 values >1600 MPN / g. This amount decreased on the 10th day for all reactors in the

309 value range $<1.8$ to 7.8 , although the compost pile temperature in $\mathrm{R} 2$ did not reach

$31040^{\circ} \mathrm{C}$. According to $\left(\underline{31)}\right.$, the removal of pathogens requires temperatures above $55^{\circ}$

$311 \mathrm{C}$ but can be damaged even at low temperatures in compost. On the 34th day, E.

312 coli increased to $350 \mathrm{MPN} / \mathrm{g}$ and $170 \mathrm{MPN} / \mathrm{g}$ at R1 and R4 while R2 and R3

313 remained at <1.8 MPN / g. This increase indicates that the previous decrease in the

314 number of E. coli does not mean that the bacteria have degraded but can also be due

315 to the bacteria becoming inactive during thermophilic conditions, then reactivating

316 when they enter a mesophilic state. 
318 of accompanying factors that cause by heat production, microorganisms competition,

319 nutrient deficiencies, or high ammonia $\left(\mathrm{NH}_{3}\right)$ concentration (31). The composting

320 duration is an essential factor in pathogens removal, where the thermophilic phase

321 should last at least one week for complete elimination of pathogens and ensuring

322 maximum sanitary conditions for composting human waste (28). The increase in the $E$.

323 coli population in compost is closely related to the availability of digestible carbon

324 and low microbiological competitiveness at the mesophilic maturation stage (34). The

325 compost storage conditions also influence the pathogen regrowth phenomenon ( $\underline{35})$

326 because composting facilities can be a significant source of aerosol pathogens (28). At

327 the end of the composting period, the E. coli concentration dropped for R1 and R4

328 into 79 and $<1.8 \mathrm{MPN} / \mathrm{g}$. It showed that the pathogen growth decline along with

329 the compost complete matured.

330 Composting microorganisms need $\mathrm{C}$ as an energy source and $\mathrm{N}$ to maintain and

331 develop cells, proteins, enzymes, and hormones (24). C / $\mathrm{N}$ ratio that is too high

332 indicates insufficient $\mathrm{N}$ for optimal microorganism growth so that decomposition

333 takes place slowly (32). A low $\mathrm{C} / \mathrm{N}$ ratio will tend to produce excessive amounts of 
$334 \mathrm{NH}_{3}$ and volatile fatty acids, which lead to the release of unpleasant odours (16), and

335 a large number of dissolved base salt, thus making the soil unsuitable for growing 336 plants $(\underline{28})$.

338 levels at the beginning of the study ranged from 2.11 to 2.12 . R2, R3, and R4 339 experienced an increase in Total $\mathrm{N}$ by $16 \%, 19 \%$, and $22 \%$. While R1 decreased by $34017 \%$, indicating a loss of nitrogen in the compost pile. The $\mathrm{C} / \mathrm{N}$ ratio was obtained 341 from the organic $\mathrm{C}$ content with the total $\mathrm{N}$ comparison, referring to several studies 342 that determined the $\mathrm{C} / \mathrm{N}$ ratio in this way. Organic $\mathrm{C}$ are measured based on carbon 343 dioxide emissions released, or the rate of microbial respiration, while total $\mathrm{N}$ is 344 nitrogen in organic and inorganic forms $(\underline{30}, \underline{33})$. 29.95. It expected that composting run effectively since the optimal $\mathrm{C} / \mathrm{N}$ ratio for

347 composting is around 25 to 30 (24). According to (32), the decomposition of organic

348 C will occur gradually along with the $\mathrm{C} / \mathrm{N}$ ratio of the material decrease, as long as

$349 \mathrm{~N}$ does not lose through gas emissions. R1 recorded an increasing $\mathrm{C} / \mathrm{N}$ ratio because 350 total $\mathrm{N}$ continued depleting. While in $\mathrm{R} 2, \mathrm{R} 3$, and $\mathrm{R} 4$, a decrease in the $\mathrm{C} / \mathrm{N}$ ratio 
351 along with the increase in total N. At the end of the composting period, the lowest $\mathrm{C} /$

$352 \mathrm{~N}$ ratio is in $\mathrm{R} 4$, which is 19.96 , which indicates the compost is mature because the $\mathrm{C}$

353 / $\mathrm{N}$ ratio below 20 is accepted indicator for maturity. Figure 3 shows changes in

354 Organic-C, Total N, and C / N Ratio during composting.

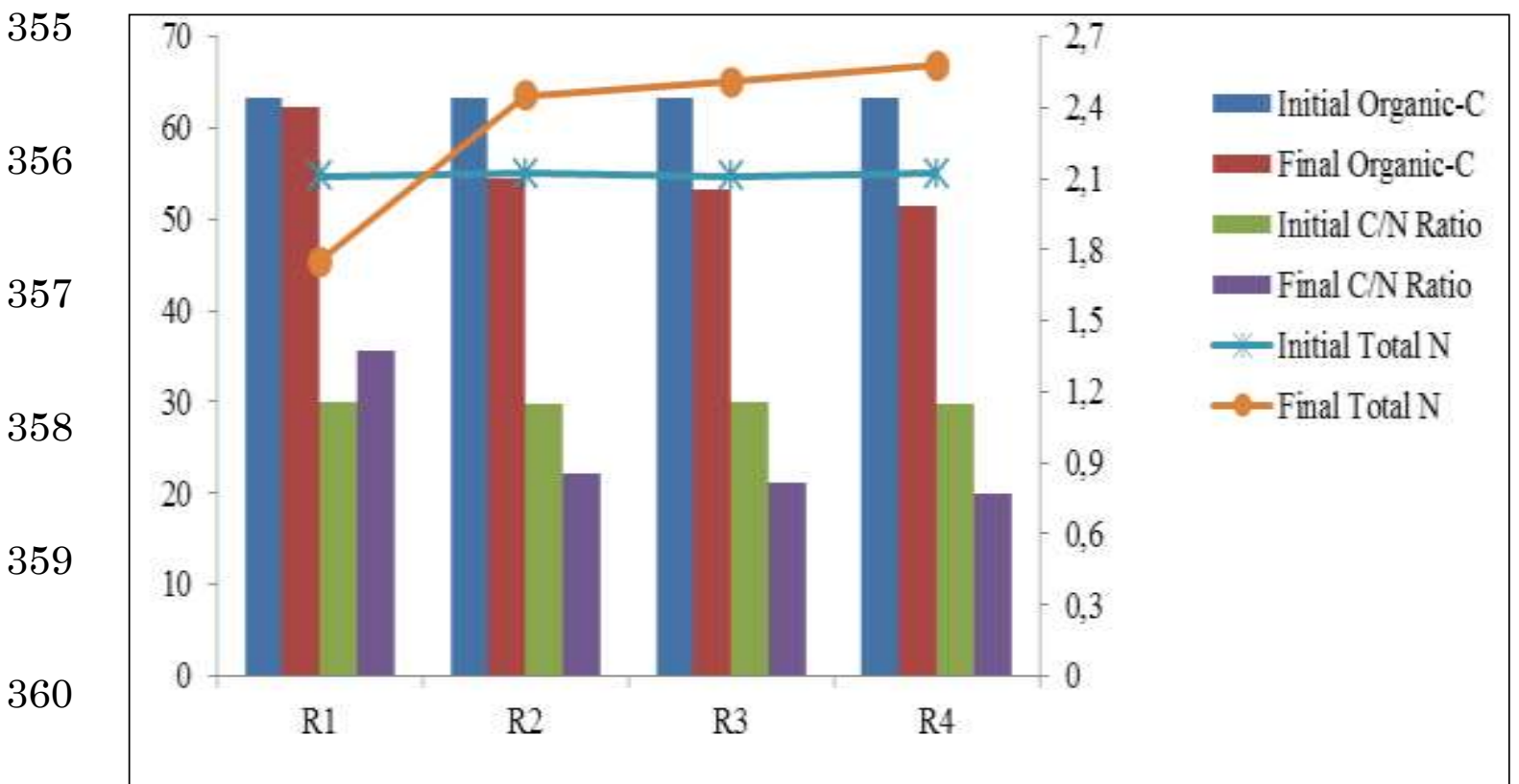

361

Fig. 3. Organic-C, Total N, and C / N Ratio during composting

362

363

\subsection{Interparameter Relations}

364 In the composting process, there is a relationship between parameters. The

365 correlation coefficient calculated for that purposes. The correlation coefficient is a

366 value that indicates whether or not a linear relationship is strong between two

367 variables. The usual correlation coefficient denoted by the r-value that varies from -1 
to +1 . The $r$-values close to -1 or +1 indicate a strong relationship between the two

369 variables. While the r-value close to 0 determine a weak relationship between the two

370 variables. The + (positive) and - (negative) signs provide information about the

371 relationship between the two variables. If it is positive, the two variables have a

372 unidirectional relationship. In another sense, an increase in $\mathrm{X}$ will coincide with an

373 increase in $\mathrm{Y}$ and vice versa. If it is negative, it means that the correlation between the

374 two variables is opposite. An increase in $\mathrm{X}$ value, accompanied by a decrease in $\mathrm{Y}$.

375 In R1, the moisture content appears to be related to Total $\mathrm{N}$ and the $\mathrm{C} / \mathrm{N}$ ratio.

376 The Total $\mathrm{N}$ falls with water content decreasing. It appears that $\mathrm{N}$ released into the air

377 through emissions along with water evaporation. The decrease in Total $\mathrm{N}$ value is

378 closely related to the increase in the $\mathrm{C} / \mathrm{N}$ ratio in $\mathrm{R} 1$, by a correlation value of -0.99 .

379 R2, R3, R4 show a close relationship between temperature and E. coli, as previously

380 described from some literature on this subject. The decrease in C-Organic related to

381 the increase in Total $\mathrm{N}$, by a correlation value of -0.98 in $\mathrm{R} 2$ and $\mathrm{R} 3$, and -0.99 in R4,

382 while Total $\mathrm{N}$ increasing accompanied by a decrease in the $\mathrm{C} / \mathrm{N}$ ratio where the

383 relative coefficient values are -0.99 . While the water content in R2, R3, and R4, when

384 connected to Total N, always shows the value - (negative). It means that the lower the 
385 water content, the higher Total N. It is related to the ammonification process, where

386 ammonia will react with water to form ammonium so that when the water content

387 decreases, the Total $\mathrm{N}$ increases. The $\mathrm{pH}$ and temperature values together can

388 influence the waste degradation process, but this study concludes that $\mathrm{pH}$ does not

389 depend on temperature where the correlation coefficient value in all reactors for $\mathrm{pH}$

390 and temperature is closer to zero. The correlation coefficient for each reactor showed

391 in Table 2.

392

$393 \quad$ 3.3. Effect of S. platensis in composting

394 ANOVA test with a P-value of 0,9999 showed that the water content in the

395 composting of diaper waste was not affected by the addition of S. platensis. The

396 perforated piping system and daily agitation reduced the moisture content in all

397 reactors faster than in the previous study, where water content is at $53.1-58.76 \%$ on

398 the 60th day of diapers composting ( $\underline{36})$.

399 In this study, the content of E. coli> $1600 \mathrm{MPN} / \mathrm{g}$ assumed to be $1650 \mathrm{MPN} / \mathrm{g}$

400 and <1.8 MPN / $\mathrm{g}$ to be $1.5 \mathrm{MPN} / \mathrm{g}$ so that calculations made for statistical analysis

401 using the ANOVA method. The C-Organic and E. coli depletions in the composting 
process with P-value 0,1358 and 0,9986 in the ANOVA test was unaffected by the addition of $S$. platensis. Co-composting between disposable diaper waste and food waste provides a diversity of microorganisms in the composting system, which is sufficient for the degradation of C-Organic and E. coli. as the temperature, P-value of 2,03E-13 showed that $S$. platensis affected $\mathrm{pH}$ in diaper composting. The low temperature and $\mathrm{pH}$ in this co-composting, if associated with cyanobacteria, is due to its ability to carry out nitrogen fixation.

411 potential of formed $\mathrm{NH}_{3}$ increases as a nitrogen fixation result, it will react with water to form $\mathrm{NH}_{4}$ (ammonium). This ammonification process prevents $\mathrm{NH}_{3}$ emissions from being released into the air. It is the reason the temperatures in the R2, R3, and R4 tend

414 to be lower than $\mathrm{R} 1$ since $\mathrm{NH}_{3}$ emissions did not occur.

416 and converts $\mathrm{NH}_{4}$ to nitrate (ㄱ) . This process causes a decrease in the $\mathrm{pH}$ value (32).

417 R2, R3, and R4 have higher nitrification potential than the control, which seen from 418 the increases of total $\mathrm{N}$ during the composting process. That is why the $\mathrm{pH}$ value is 
419 almost always lower than the $\mathrm{pH}$ of $\mathrm{R} 1$ that does not contain Spirulina. With plenty of

420 Total $\mathrm{N}$ due to nitrogen fixation, the ANOVA test with a P-value of 0,0003 showed

421 the effect of $S$. platensis inoculation on the $\mathrm{C} / \mathrm{N}$ ratio in composting this diaper 422 waste.

423

424 3.4. Compost degradation rate

425 The rate of degradation determined by the level of inactivation of microorganisms

426 using the D value. It knowns as the Decimal reduction time. Determining the D value

427 can be done by plotting the time (days) and the $\log \mathrm{N}$ value of $\mathrm{C}$-Organic ( $\underline{36})$.

428 Likewise, not all inactivation described by a constant D-value. Some processes return

429 inactivation curves with a profile similar to the inverse of a growth curve. In these

430 curves, it is possible to define a shoulder (that is, the period before the number of

431 living cells begins to decrease) where the cells had not received enough damage to

432 start dying. When a critical amount of damage occurred, the inactivation phase began.

433 Then a tail phase (that is, the period where no further reduction achieved). Not all

434 curves exhibit all three stages. Sometimes only two are noticeable (표).

435 Overall, in cyanobacteria composting, all the parameters reached stable condition 
436 after 18 days (29), and the organic matter reduced by $7.46 \%$ to $10.33 \%$ on the 24 th

437 day (ㅁ). Meanwhile, in this composting, until days 34, the curve showed the shoulders

438 because, during this initial period, Spirulina need a couple of time to adapt to the

439 composting environment before they do the waste degradation rapidly. The highest D

440 value is R1, followed by R2, R3, and R4. It means a composting system in R4 has the

441 fastest degradation rate compare to others. This profile described with the Exponential

442 graph of Log N vs Composting Time seen in Figure 4.

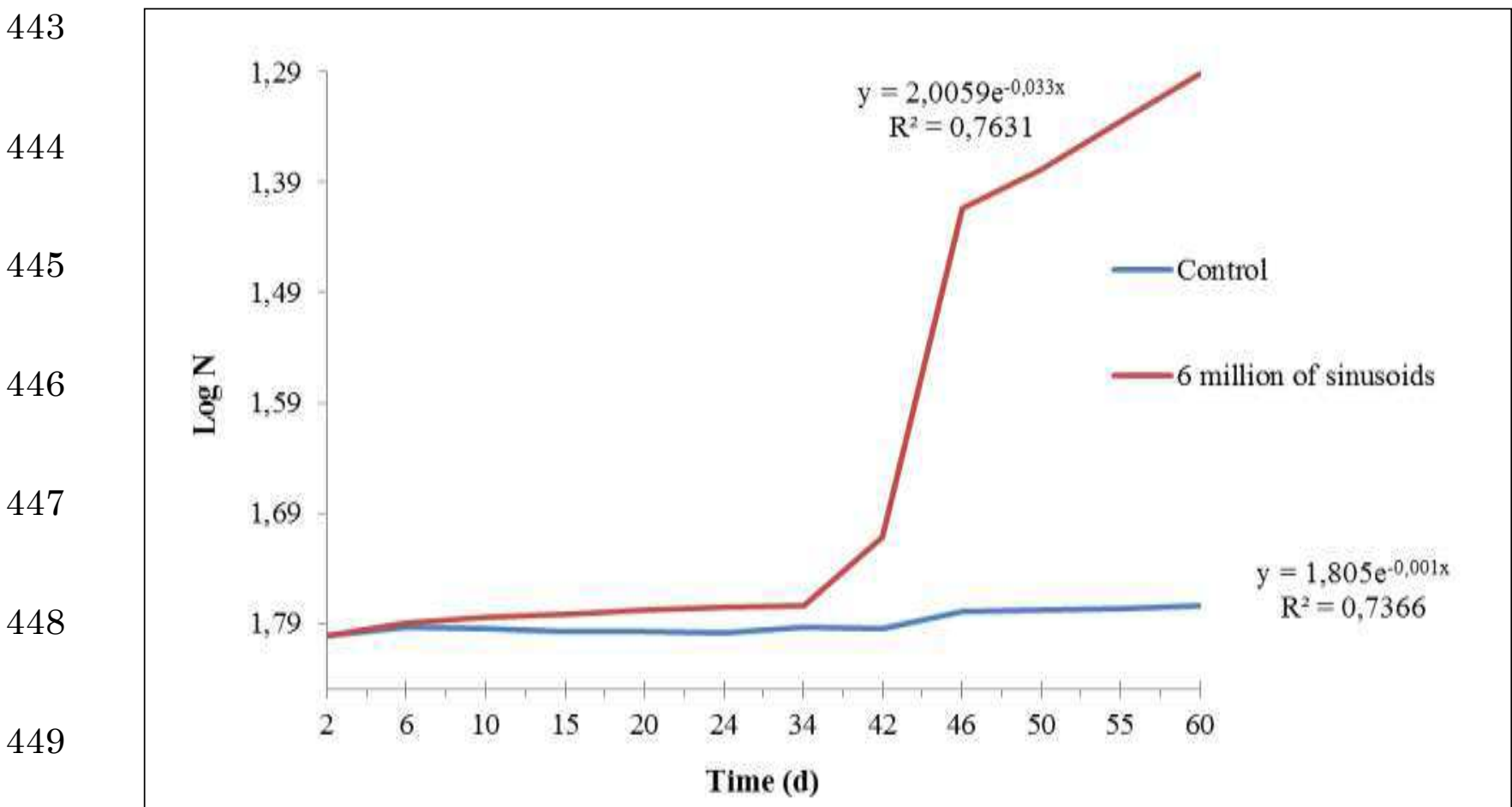

Fig. 4. Log N vs Composting Time

451 The degradation was slow compared to other organic waste composting because

452 cellulose, LDPE and PP polymers from disposable diaper waste were unseparated. 
453 Composting cellulose is known to require a long time, in which the bioconversion

454 process of lignocellulose under natural conditions is six months (24). Meanwhile,

455 plastic polymers are unexpected material present in the composting system, apart

456 from glass, metal, stone, and any other non-stone fragments $>2 \mathrm{~mm}$, and weed seeds,

457 which can negatively affect plant growth (27). However, in household-scale diaper

458 composting, separating LDPE and PP polymers from disposable diaper waste is

459 difficult because of the human waste that adheres to the diaper material. And

460 disposing of plastic polymer material contaminated with human waste to the landfill

461 will leave problems in terms of waste collection, transporting waste and handling

462 plastics in the landfill, which requires costs and energy, also possibility of pathogen

463 transmission.

464

465 3.5.Compost quality

466 The quality of compost largely determines the overall productivity in the waste

467 degradation process. Maturity and stability are two critical parameters that assess

468 compost quality. The term maturity validates the compost suitability for agricultural

469 purposes, subject to biological and chemical effects. While the stability is indirectly 
470 linked to microbial activity, judging the proper humidification of the organic fraction

471 (32). Unstable or immature compost deliver negative impacts for seed germination,

472 plant growth and the soil due to oxygen supply reduction, insufficient available

473 nitrogen, or the phytotoxic compounds present (느). Integrated evaluation obtained

474 through principal component analysis, linking physicochemical indicators with

475 biological and ecotoxicological indicators. This study uses parameters including $\mathrm{pH}$,

476 temperature, moisture content, $\mathrm{C} / \mathrm{N}$ ratio for physical and chemical indicators and

477 levels of pathogens for biological indicators. The GI (Germination Index) value as an

478 ecotoxicological indicator.

479 Table 3 shows the quality of compost produced in R4 compared to the Indonesian

480 Regulatory Standard. These results show that the water content is still above the

481 quality standard viewed from the Decree of the Minister of Agriculture of the

482 Republic Indonesia (41). This problem solving is drying the compost. Meanwhile, the

483 C-Organic value exceeds the Indonesian National Standard (42). The suggested

484 resolution is by increasing the dose or density of inoculants considering the potential

485 of S. platensis in accelerating the rate of C-Organic degradation and biodegradation of

486 plastics. The low $\mathrm{pH}$ overcome by adding natural alkaline ingredients to neutralize the 
$\mathrm{pH}$ of the compost.

The final compost material in this study appears to leave rice husks, cellulose and

489 plastic scraps. Although the water content in all reactors is not too big a difference,

490 R2, R3, and R4 appear more moist and oily because the oil content of S. platensis is

491 4-17 (\% dry weight) (느). The compost was not milled or sieved, but all parts used in

492 the phytotoxicity test. It causes the compost is not homogeneous and possible the

493 presence of phytotoxins from the remaining plastic polymer.

3.6.Phytotoxicity test

Observation shows that maize plants are better able to withstand the effects of

497 phytotoxins to sprout up to the 4th polybag, while cayenne pepper plants only to the

498 2nd polybag. However, normal seed germination emerged in Polybag 1 (P1) as

499 control and Polybag 2 (P2). Figure 5 shows the seeds germination in all samples

500 compared to controls, which resulted in $133 \%$ for maize and $100 \%$ cayenne pepper.

501

502

503 


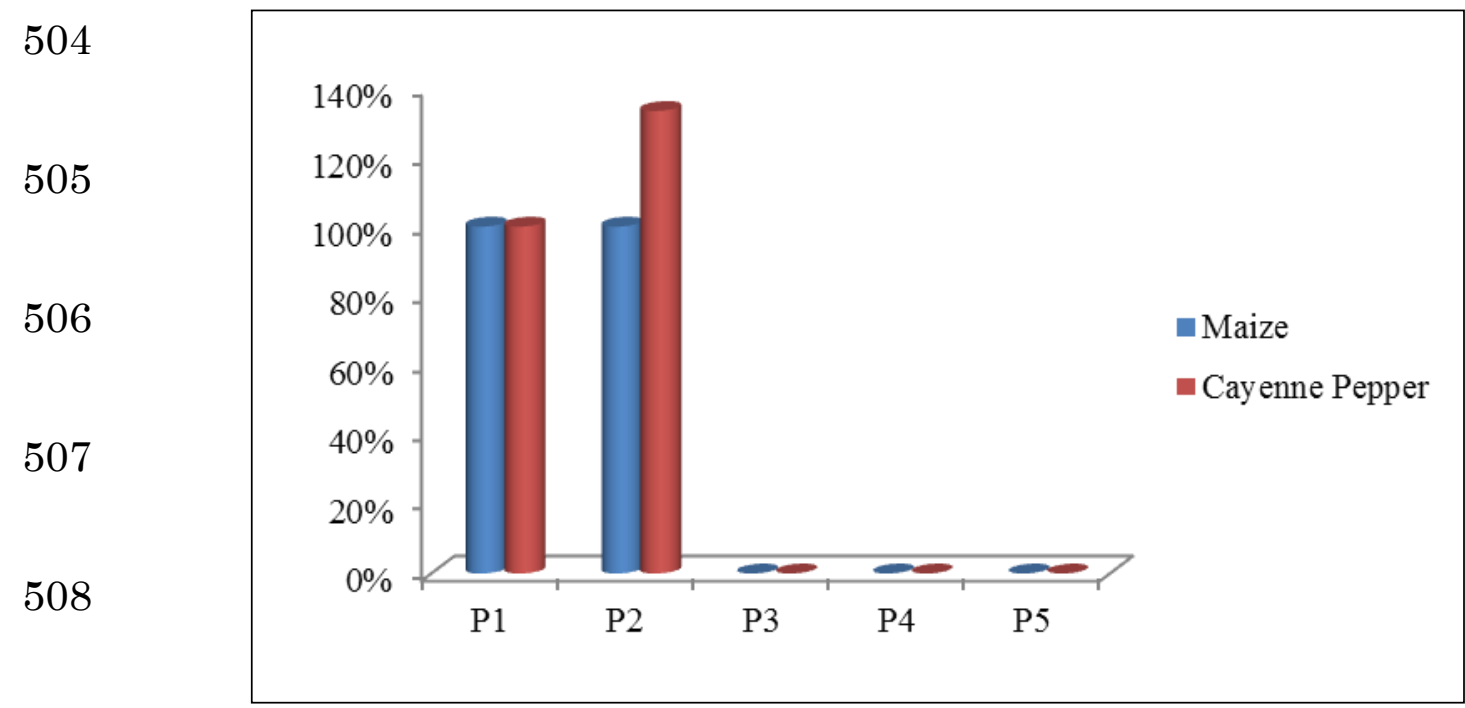

509

Fig. 5. RSG for maize and cayenne pepper

510 P2 showed that maize roots were thicker, interconnected among sprouts, and even

511 penetrated the diapers cellulose so that it was difficult to separate and measure, while

512 maize roots in P1 had almost the same length but not as thick as in P2. Since maize is

513 filamentous and impossible to count individually, the average of three roots used

514 representing the long, medium, and shortest ones. The cayenne pepper grew in the

515 control soil presented slightly higher shoot and root longer than those cultivated on P2.

516 While in P2, the stem diameter appears larger. The ANOVA analysis confirmed the

517 observation; the compost composition affected SG and RSG presented a P-value of

5180,0004 and 0,0007 , respectively, while the plant type does not affect. The

519 Germination Index (GI) for maize is $124 \%$, and cayenne pepper, 83\%. Considering

520 the GI maize exceeding $100 \%$, based on a compost phytotoxicity study, the compost 
521 composition can be used as a phytonutrient, while cayenne pepper, the GI value is

522 lower, but above $80 \%$, indicating that compost does not have a phytotoxin effect on

523 plants $(\underline{26})$.

524 The composting effect on other plants requires further research on the compost

525 application to various types of plants, representing agricultural, horticultural, and

526 forestry plants, to link the resulting compost to resource sustainability. The authors

527 recommend not only the germination test but until the plants bear fruit to know the

528 long-term toxicity effects of compost on these plants. It is essential to identify

529 different plant behaviour in the growing media that the compost is applied because the

530 compost still contains high levels of carbon while at a certain level, carbon can

531 increase growth, but at high levels, it can reduce growth. Therefore, a phytotoxicity

532 test required to ensure the range of compost concentrations in planting media that

533 does not lethal plants (4ㅜ).

534 The compost utilization can also associate with phytoremediation because of

535 cyanobacteria content in the compost, as the use of cyanobacteria is prospective for

536 environmental quality improvement by restoration of polluted environments (45).

537 However, it needs to test several plants since there are kinds of plants to eliminate 
different contaminants. One of them is indoor phytoremediation using decorative

539 plants, related to the new habits of the people nowadays who use limited land or

540 indoors for greening. It brings advantages to maintaining environmental health (뜨).

\section{Conclusion}

543

S. platensis accelerated the composting time from 60-106 days in the previous

544 study to 42 days. The best degradation rate obtained in the composting system by 6.0

545 millions sinusoids of S. platensis addition. Since no analysis of Spirulina final density,

546 its growth is unknown. There is the potential for a faster degradation rate than the

547 denser S. platensis or from more doses. More investigation needed at several

548 variations, or with a Spirulina density above 60,000 sinusoids/ml, with a density test

549 at the initial and end of the study. Also, the possibility of Spirulina degrading the

550 plastic and microplastics that might present in the compost trigger to do detailed

551 research. S. platensis enriches the compost nutrients in the form of Total N due to its

552 nitrogen-fixing ability. It recorded from the Total $\mathrm{N}$ at the final stage in $\mathrm{R} 4$ was $47 \%$

553 greater than R1, while as at the beginning of composting, the difference was only

$5540.5 \%$. This gap caused by increasing $22 \%$ Total $\mathrm{N}$ at $\mathrm{R} 4$ while decreasing occurs in

555 R1. Given the high GI value on the phytotoxicity test from the composition of soil: 
compost is $7: 3$, it concluded that the presence of degraded polymers did not affect the potential utilization of compost as a growing medium for maize and cayenne pepper. Home scale composting diaper waste can be a solution for the community with

559 a lack of budget for waste management. Nevertheless, this is not widely practised in

560 waste management by the community yet. Diaper waste is often categorized as

561 residue and ends up in the landfill or even in water bodies. According to this study

562 result, that $S$. platensis enhancing disposable diapers composting, both in the process,

563 as well as the utilization of compost, it is recommended to apply this method so that

564 the community can save on waste collection costs to the dumpsite, transportation

565 costs and waste management at the landfill, labour costs, and stop the risk of exposure

566 to pathogens to the labour and residents around the landfill. Besides, waste

567 management in which the community plays the role with the government fully

568 support will bring sustainability. Therefore, it is necessary to continue making efforts

569 to socialize and educate the public about this promising method, further research on

570 large applications and economic value, including market research of this compost

571 product. So it will not only give advantages for environmental sustainability but also

572 economically beneficial. 


\section{ABBREVIATIONS}

\begin{tabular}{|c|c|}
\hline ANOVA & Analysis of Variance \\
\hline$C$ & Carbon \\
\hline$C / N$ ratio & Carbon to nitrogen ratio \\
\hline$D$ & Decimal reduction time \\
\hline$D D T$ & Dichloro Diphenyl Trichloroethane \\
\hline E. coli & Escherichia coli \\
\hline EDTA & Ethylenediaminetetraacetic acid \\
\hline $\mathrm{FeCl}_{3}$ & Ferric chloride \\
\hline$G I$ & Germination Index \\
\hline$L D P E$ & Low-Density Polyethylene \\
\hline$M P N$ & Most Probable Numbers \\
\hline$N$ & Nitrogen \\
\hline $\mathrm{NH}_{3}$ & Ammonia \\
\hline $\mathrm{NH}_{4}$ & Ammonium \\
\hline S. platensis & Spirulina platensis \\
\hline
\end{tabular}




$\begin{array}{ll}P & \text { Polybag } \\ P P & \text { Polypropylene } \\ P \text {-value } & \text { Probability value } \\ P V C & \text { Polyvinyl Chloride } \\ R & \text { Reactor } \\ R S G & \text { Relative Seed Germination } \\ S A P & \text { Super Absorbent Polymer } \\ & \\ S G & \text { Seed Germination } \\ \text { ZNI } & \text { Standar Nasional Indonesia } \\ & \end{array}$

$578 \quad$ Availability of data and materials

579 The dataset supporting the conclusions of this article is available in the Mendeley

580 Data repository at https://data.mendeley.com/datasets/r4329wpzvf/1. 


\section{Competing interests}

583 The authors declare they have no competing interests.

584

$585 \quad$ Funding

586 This work funded by the Ministry of Finance of the Republic of Indonesia through

587 Lembaga Pengelola Dana Pendidikan (LPDP). The scholarship numbers:

$588 \quad$ KET-1460/LPDP.3/2018.

590 Authors' contributions

591 Diana Indah Kusumawati: Conceptualization, performed the literature review, formal

592 analysis, investigation, writing-original draft, visualization, administration, obtaining

593 funding. Sarwoko Mangkoedihardjo: Conceptualization, methodology, supervision.

594 critical revision of the manuscript for important intellectual content.

595 All authors read and approved the final manuscript.

596

\section{Acknowledgements}

598 The authors would like to thank the Department of Environmental Engineering, 
599 Faculty of Civil, Planning and Geo-Engineering at Institut Teknologi Sepuluh

600 Nopember (ITS) and Department of Environment of Pasuruan Regency for providing

601 the support to conduct the above research.

602

603 References

604 1. Khoo SC, Phang XY, Ng CM, Lim KL, Lam SS, Ma NL. Recent technologies

605 for treatment and recycling of used disposable baby diapers. Process Saf.

$606 \quad$ Environ. Prot. 2019;123:116-129.

607 2. Budyk Y, Fullana A. Hydrothermal carbonization of disposable diapers. J.

$608 \quad$ Environ. Chem. Eng. 2019;7(5):103341.

609 3. Mihelcic JR, Fry LM, Shaw R. Global potential of phosphorus recovery from

610 human urine and feces. Chemosphere. 2011;84:832-839.

611 4. Al-jabari M, Ghyadah RA, Alokely R. Recovery of hydrogel from baby diaper

612 wastes and its application for enhancing soil irrigation management. J. Environ.

613

Manage. 2019;239:255-261.

614 5. Kumar RV, Kanna GR, Elumalai S. Biodegradation of Polyethylene by Green

615 Photosynthetic Microalgae. J. Biorem. 2017;8(1):1-8. 
616 6. Kusumawati DI, Mangkoedihardjo S. Promising approach for composting disposable diapers enhanced by Cyanobacteria. Global J. Environ. Sci. Manage.

618 $2021 ; 7(3): 1-18$.

619

7. Arab G, Razaviarani V, Sheng Z, Liu Y, McCartney D. Benefits to decomposition rates when using digestate as compost co-feedstock: Part II Focus on microbial community dynamics. Waste Manage. 2017;68:85-95.

622 8. Han S, Li J, Zhou Q, Liu G, Wang T. Harmless disposal and resource utilization evaluation of fertilizer. Algal Res. 2019;43:101623.

625

9. Lu W, Alam MA, Luo W, Asmatulu E. Integrating Spirulina platensis cultivation and aerobic composting exhaust for carbon mitigation and biomass production. Bioresour. Technol. 2019;271:59-65.

628 10. Yadav S, Rai R, Shrivastava AK, Singh PK, Sen S, Chatterjee A, Rai AS, Singh S, Rai L.C. Cyanobacterial Biodiversity and Biotechnology: A Promising Approach for Crop Improvement. In New and Future Developments in 
633 11. Renuka N, Guldhe A, Prasanna R, Singh P, Bux F. Microalgae as 634 multi-functional options in modern agriculture : current trends, prospects and challenges. Biotechnol. Adv. 2018;36(4):1255-1273.

636

12. Kurashvili M, Varazi T, Khatisashvili G, Gigolashvili G, Adamia G, Pruidze M, et al. Blue-green alga Spirulina as a tool against water pollution by 1,1-(2,2,2-trichloroethane-1,1-diyl)bis(4-chlorobenzene).(DDT). Ann. Agrar. Sci. 2018;16(4):405-409.

640 13. Sarmah P, Rout J. Role of algae and cyanobacteria in bioremediation: prospects in polyethylene biodegradation. In Advances in Cyanobacterial Biology.

643 14. Alobwede E, Leake JR, Pandhal J. Circular economy fertilization: Testing micro and macro algal species as soil improvers and nutrient sources for crop production in greenhouse and field conditions. Geoderma. 2019;334:113-123.

646 15. Soni RA, Sudhakar K, Rana RS. Spirulina - From growth to nutritional product: A review. Trends Food Sci. Technol. 2017; 69:157-171.

648 16. Lin L, Xu F, Ge X, Li Y. Biological treatment of organic materials for energy and nutrients production-Anaerobic digestion and composting. In Advances 
in Bioenergy. Elsevier Inc. 2019;4:121-181.

651 17. Cerda A, Artola A, Font X, Barrena R, Gea T, Sánchez A. Composting of food wastes: Status and challenges. Bioresour. Technol. 2018;248:57-67.

653

18. Bian B, Hu X, Zhang S, Lv C, Yang Z, Yang W, et al. Pilot-scale composting of typical multiple agricultural wastes : Parameter optimization and mechanisms. Bioresour Technol. 2019;287:121482.

19. Tucho G.T, Okoth T. Evaluation of neglected bio-wastes potential with food-energy- sanitation nexus. J. Cleaner Prod. 2020;242:118547.

20. Espinosa-Valdemar RM, Turpin-Marion S, Delfín-Alcalá I, Vázquez-Morillas Manage. 2011;31:1683-1688. application and toxic risk of used diaper and food waste as growth substitute for sustainable cultivation of oyster mushroom (Pleurotus ostreatus). J. Cleaner Prod. 2020;268:122272.

22. Espinosa-Valdemar RM, Sotelo-Navarro PX, Quecholac-Pina X, García-rivera, 
recycling of used baby diapers in a small-scale composting system. Resour. Conserv. Recycl. 2014; 87:153-157.

23. Rudnik E. Ecotoxicological assessment of compostable polymer materials. In Compostable polymer materials. Elsevier Ltd. 2019;2:293-313.

24. Harindintwali JD, Zhou J, Yu X. Lignocellulosic crop residue composting by sustainability. Sci. Total Environ. 2020;715:136912.

25. Fan YV, Lee CT, Klemes JJ, Chua LS, Sarmidi MR, Leow CW. Evaluation of Manage. 2017;216:41-48.

26. Barral MT, Paradelo R. A review on the use of phytotoxicity as a compost quality indicator. Dyn. Soil Dyn. Plant. 2011;5(2):36-44.

27. Rudnik E. Definitions, structures and methods of preparation. In Compostable polymer materials. Elsevier Ltd. 2019;2:11-48

681 28. Onwosi CO, Igbokwe VC, Odimba JN, Eke IE, Nwankwoala MO, Iroh IN, et 682 al. Composting technology in waste stabilization: On the methods, challenges and future prospects. J. Environ. Manage. 2017;190:140-157. 
684 29. Guo, XX, Liu HT, Wu SB. Humic substances developed during organic waste composting: Formation mechanisms, structural properties, and agronomic functions. Sci. Total Environ. 2019;662:501-510.

30. Rudnik E. Composting methods and legislation. In Compostable polymer materials. Elsevier Ltd. 2019;2:127-161.

689

31. Bernal MP, Sommer SG, Chadwick D, Qing C, Guoxue L, Michel FC. Current approaches and future trends in compost quality criteria for agronomic, Inc. $2017 ; 144: 143-233$.

32. Rastogi M, Nandal M, Khosla B. Microbes as vital additives for solid waste composting. Heliyon. 2020;6:e03343.

33. Mangkoedihardjo S. Revaluation of maturity and stability indices for compost. microbial faecal indicators during small scale co-composting of faecal matter. Waste Manage. 2010;30(2):185-191. 
abiotic factors on human pathogens in a finished compost. Water Res. 2004;38:1963-1970.

703 36. Simamora MS, Pandebesie E. Co-composting sampah popok sekali pakai (diapers) dengan sampah sayur menggunakan aerob komposter. In Undergraduate thesis, Institut Teknologi Sepuluh Nopember. 2019;1-167.

706 37. Abatenh E, Gizaw B, Tsegaye Z, Tefera G. Microbial function on climate change - a review. Environ. Pollut. Climate Change. 2018;2(1):1-7.

708 38. Perni S. Microbial control and safety in inhalation devices. In Inhaler devices: fundamentals, design and drug delivery. Woodhead Publishing Ltd.

711 39. Wang Y, Husain T. Use of Blue Green Algae to improve the chemical quality of municipal solid waste compost. The Harris Center Memorial University.2015.

713 40. Luo Y, Liang J, Zeng G, Chen M, Mo D, Li G, et al. Seed germination test for toxicity evaluation of compost: Its roles, problems and prospects. Waste Manage. 2018;71:109-114.

41. Keputusan Menteri Pertanian. Persyaratan Teknis Minimal Pupuk Organik, 

Kementerian Pertanian Republik Indonesia, Jakarta.

719 42. Standar Nasional Indonesia. Spesifikasi kompos dari sampah organik domestik. SNI 19-7030-2004, Badan Standardisasi Nasional, Jakarta.

43. Gupta V, Ratha SK, Sood A, Chaudhary V, Prasanna R. New insights into the biodiversity and applications of cyanobacteria ( blue-green algae ) — Prospects and challenges. Algal Res. 2013;2(2):79-97.

724 44. Mangkoedihardjo S, Samudro G. Research Strategy on Kenaf for Phytoremediation of Organic Matter and Metals Polluted Soil. Adv. Environ. Biology. 2014;8(17):64-67. environmental improvement - A Review. J. Arid. Agric. 2021;7:9-14. plants: An overview of application principles. J. Phytol. 2020;13:028-032.

731

732

733 
Table 1. Characteristics of Feedstock Materials and Compost

\section{Initial Characteristics of}

\section{Characteristics of}

Parameter

Feedstock Materials

Compost

\begin{tabular}{lcccccccc} 
& $\mathbf{R 1}$ & $\mathbf{R 2}$ & $\mathbf{R 3}$ & $\mathbf{R 4}$ & $\mathbf{R 1}$ & $\mathbf{R 2}$ & $\mathbf{R 3}$ & $\mathbf{R 4}$ \\
\hline $\mathrm{pH}$ & 6,3 & 6,2 & 6,0 & 6,2 & 7,0 & 6,0 & 5,5 & 5,8 \\
Temperature $\left({ }^{\circ} \mathrm{C}\right)$ & 29,3 & 29,7 & 30,0 & 31,0 & 29,0 & 29,0 & 28,7 & 29,0 \\
Organic C & 63,2 & 63,3 & 63,2 & 63,3 & 62,3 & 54,5 & 53,3 & 51,5 \\
Total N & 2,11 & 2,12 & 2,11 & 2,12 & 1,75 & 2,45 & 2,51 & 2,58 \\
C/N Ratio & 29,95 & 29,86 & 29,95 & 29,86 & 35,60 & 22,24 & 21,24 & 19,96 \\
Moisture Content & 73,3 & 74,6 & 75 & 75 & 49,7 & 52,1 & 51,2 & 50,1 \\
E.coli (MPN/g) & $>1600$ & $>1600$ & $>1600$ & $>1600$ & 79 & $<1,8$ & 26 & $<1,8$ \\
\hline
\end{tabular}

736

737

738

739

740

741

742

743

744

745

746 
Table 2. Interparameter Relations

\begin{tabular}{|c|c|c|c|c|c|c|c|}
\hline $\mathbf{R} 1$ & $\mathrm{pH}$ & Temperature & Moisture & $\mathrm{C}$ & $\mathrm{N}$ & C/N Ratio & E. coli \\
\hline $\mathrm{pH}$ & 1 & & & & & & \\
\hline Temperature & $-0,26$ & 1 & & & & & \\
\hline Moisture content & $-0,36$ & 0,86 & 1 & & & & \\
\hline $\mathrm{C}$ & $-0,25$ & 0,01 & 0,22 & 1 & & & \\
\hline $\mathrm{N}$ & $-0,33$ & 0,86 & 0,99 & 0,28 & 1 & & \\
\hline C/N Ratio & 0,32 & $-0,88$ & $-0,99$ & $-0,21$ & $-1,00$ & 1 & \\
\hline E. coli & $-0,33$ & 0,61 & 0,63 & 0,10 & 0,71 & $-0,69$ & 1 \\
\hline $\mathbf{R} 2$ & $\mathrm{pH}$ & Temperature & Moisture & $\mathrm{C}$ & $\mathrm{N}$ & C/N Ratio & E. coli \\
\hline $\mathrm{pH}$ & 1 & & & & & & \\
\hline Temperature & $-0,20$ & 1 & & & & & \\
\hline Moisture content & 0,07 & 0,84 & 1 & & & & \\
\hline $\mathrm{C}$ & $-0,27$ & 0,59 & 0,75 & 1 & & & \\
\hline $\mathrm{N}$ & 0,35 & $-0,46$ & $-0,64$ & $-0,98$ & 1 & & \\
\hline C/N Ratio & $-0,31$ & 0,55 & 0,72 & 1,00 & $-0,99$ & 1 & \\
\hline E. coli & $-0,31$ & 0,93 & 0,76 & 0,49 & $-0,38$ & 0,46 & 1 \\
\hline $\mathbf{R 3}$ & $\mathrm{pH}$ & Temperature & Moisture & $\mathrm{C}$ & $\mathrm{N}$ & C/N Ratio & E. coli \\
\hline $\mathrm{pH}$ & 1 & & & & & & \\
\hline Temperature & $-0,04$ & 1 & & & & & \\
\hline Moisture content & 0,52 & 0,73 & 1 & & & & \\
\hline $\mathrm{C}$ & 0,07 & 0,62 & 0,80 & 1 & & & \\
\hline $\mathrm{N}$ & $-0,07$ & $-0,46$ & $-0,72$ & $-0,98$ & 1 & & \\
\hline C/N Ratio & 0,08 & 0,57 & 0,78 & 1,00 & $-0,99$ & 1 & \\
\hline E. coli & 0,07 & 0,94 & 0,74 & 0,52 & $-0,37$ & 0,48 & 1 \\
\hline R4 & $\mathrm{pH}$ & Temperature & Moisture & $\mathrm{C}$ & $\mathrm{N}$ & C/N Ratio & E. coli \\
\hline $\mathrm{pH}$ & 1 & & & & & & \\
\hline Temperature & 0,06 & 1 & & & & & \\
\hline Moisture content & 0,20 & 0,65 & 1 & & & & \\
\hline $\mathrm{C}$ & $-0,09$ & 0,60 & 0,78 & 1 & & & \\
\hline $\mathrm{N}$ & 0,005 & $-0,54$ & $-0,74$ & $-0,99$ & 1 & & \\
\hline C/N Ratio & $-0,04$ & 0,59 & 0,79 & 1,00 & $-0,99$ & 1 & \\
\hline E. coli & $-0,20$ & 0,84 & 0,71 & 0,51 & $-0,39$ & 0,49 & 1 \\
\hline
\end{tabular}


Table 3. The compost quality compared to the Indonesian Regulatory Standard

\begin{tabular}{lccc}
\hline \multicolumn{1}{c}{ Parameter } & Compost & $\begin{array}{c}\text { The Decree of } \\
\text { the Minister of Agriculture } \\
\text { 261/KPTS/SR.310/M/4/2019 }\end{array}$ & $\begin{array}{c}\text { SNI } \\
\mathbf{1 9 - 7 0 3 0 - 2 0 0 4}\end{array}$ \\
\hline $\mathrm{pH}$ & 5,8 & $4-9$ & $6,8-7,5$ \\
Temperature $\left({ }^{\circ} \mathrm{C}\right)$ & 29,0 & - & $\begin{array}{c}\text { groundwater } \\
\text { temperature }\end{array}$ \\
Organic C & 51,5 & $>15$ & $9,8-32$ \\
Total N & 2,58 & - & 0,4 \\
C/N Ratio & 19,96 & $\leq 25$ & $10-20$ \\
Moisture Content & 50,1 & $10-25$ & 50 \\
E.coli (MPN/g) & $<1,8$ & $<1 \times 10^{2}$ & - \\
\hline
\end{tabular}




\section{Figures}

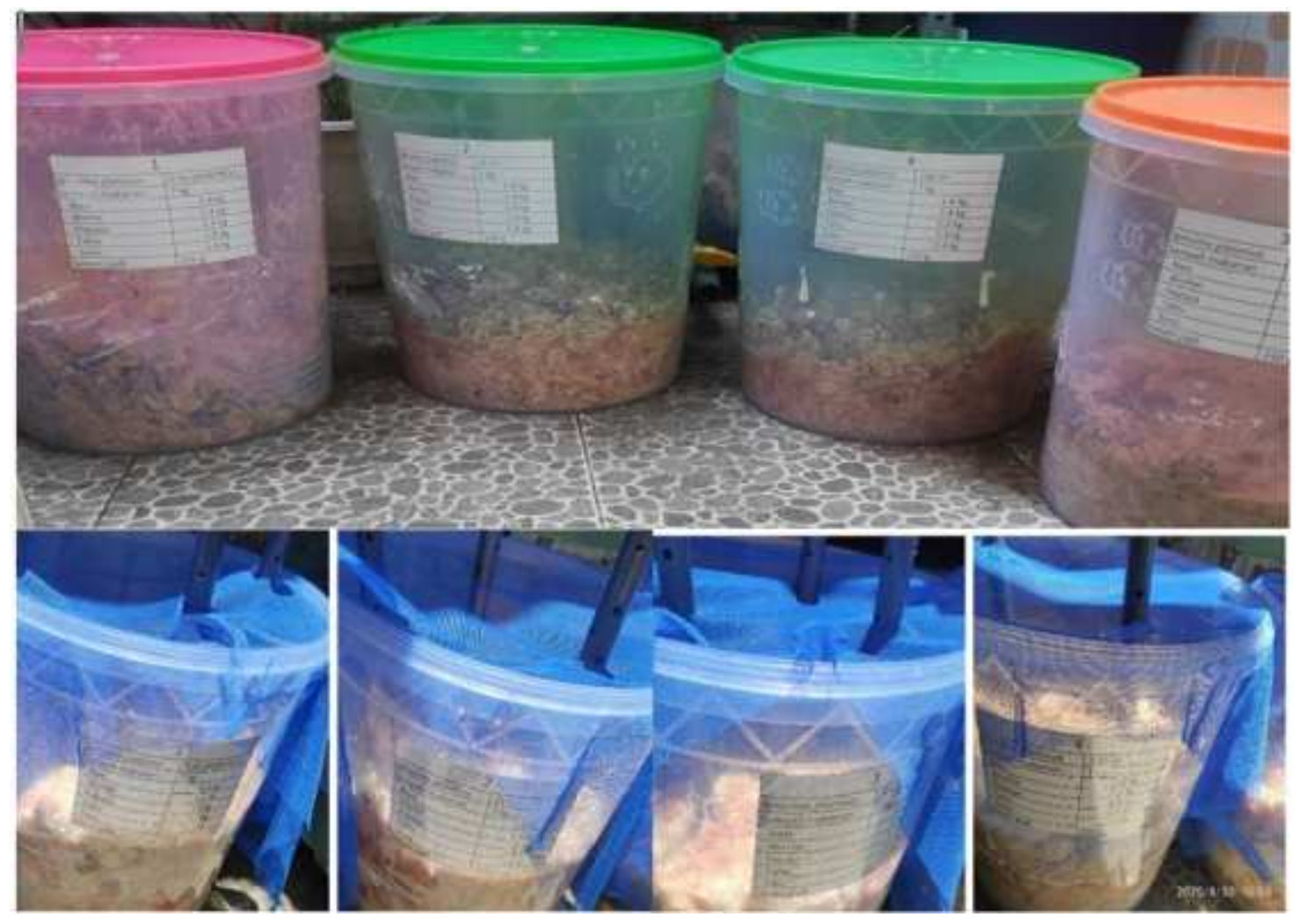

Figure 1

Composting reactor with lid and aeration pipe 


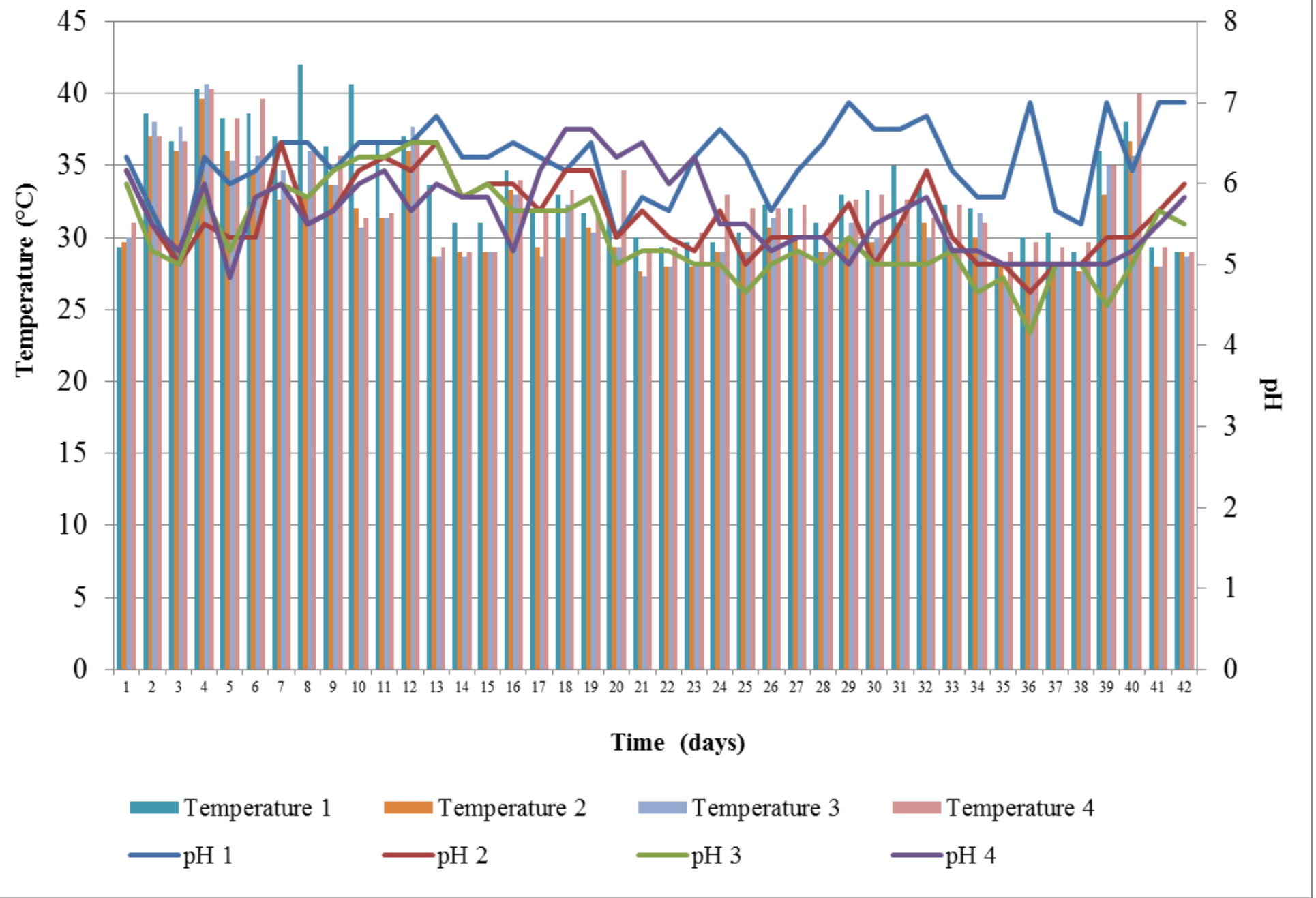

Figure 2

Temperature and $\mathrm{pH}$ during composting

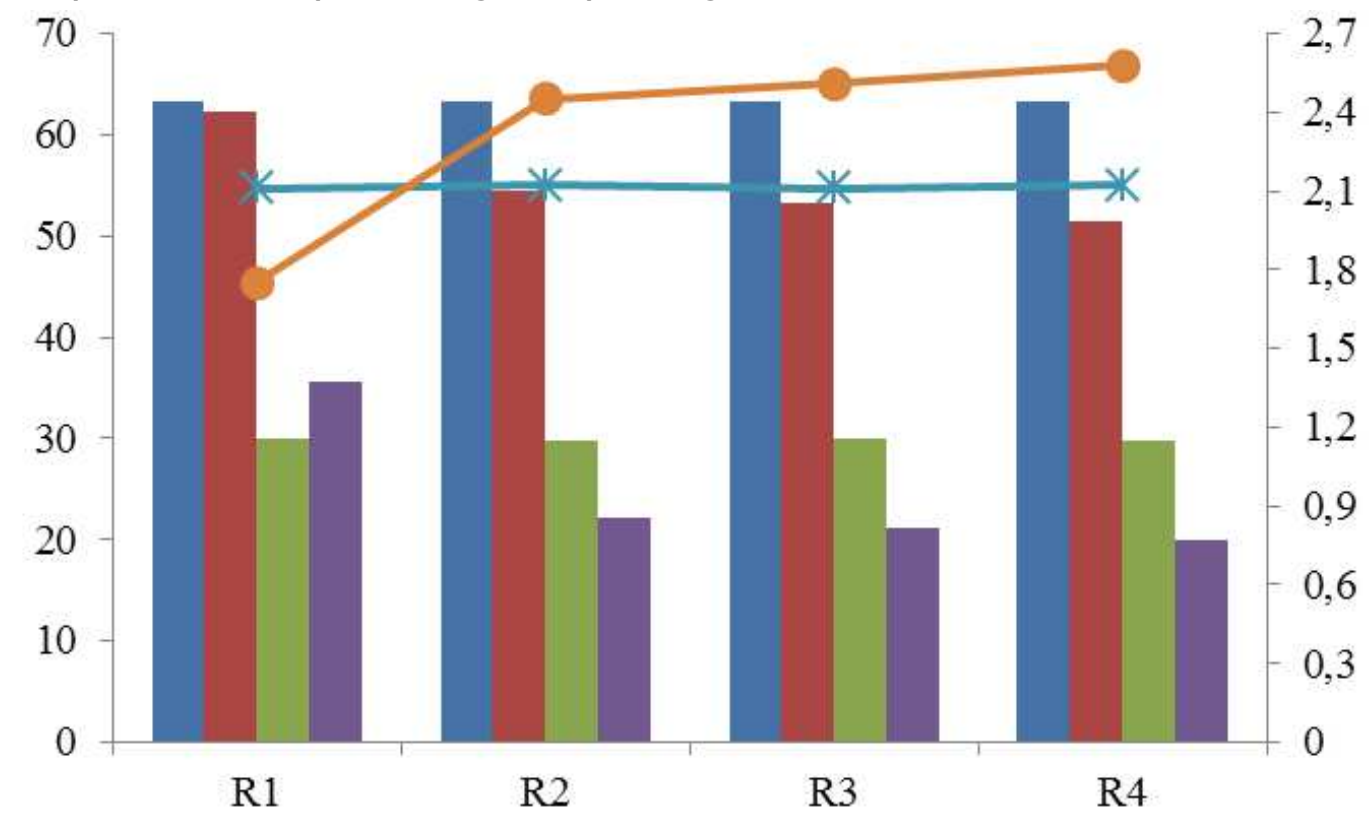

Initial Organic-C

Final Organic-C

Initial C/N Ratio

Final C/N Ratio

* Initial Total N

$\rightarrow$ Final Total $\mathrm{N}$

R3

$\mathrm{R} 4$ 
Figure 3

Organic-C, Total N, and C / N Ratio during composting

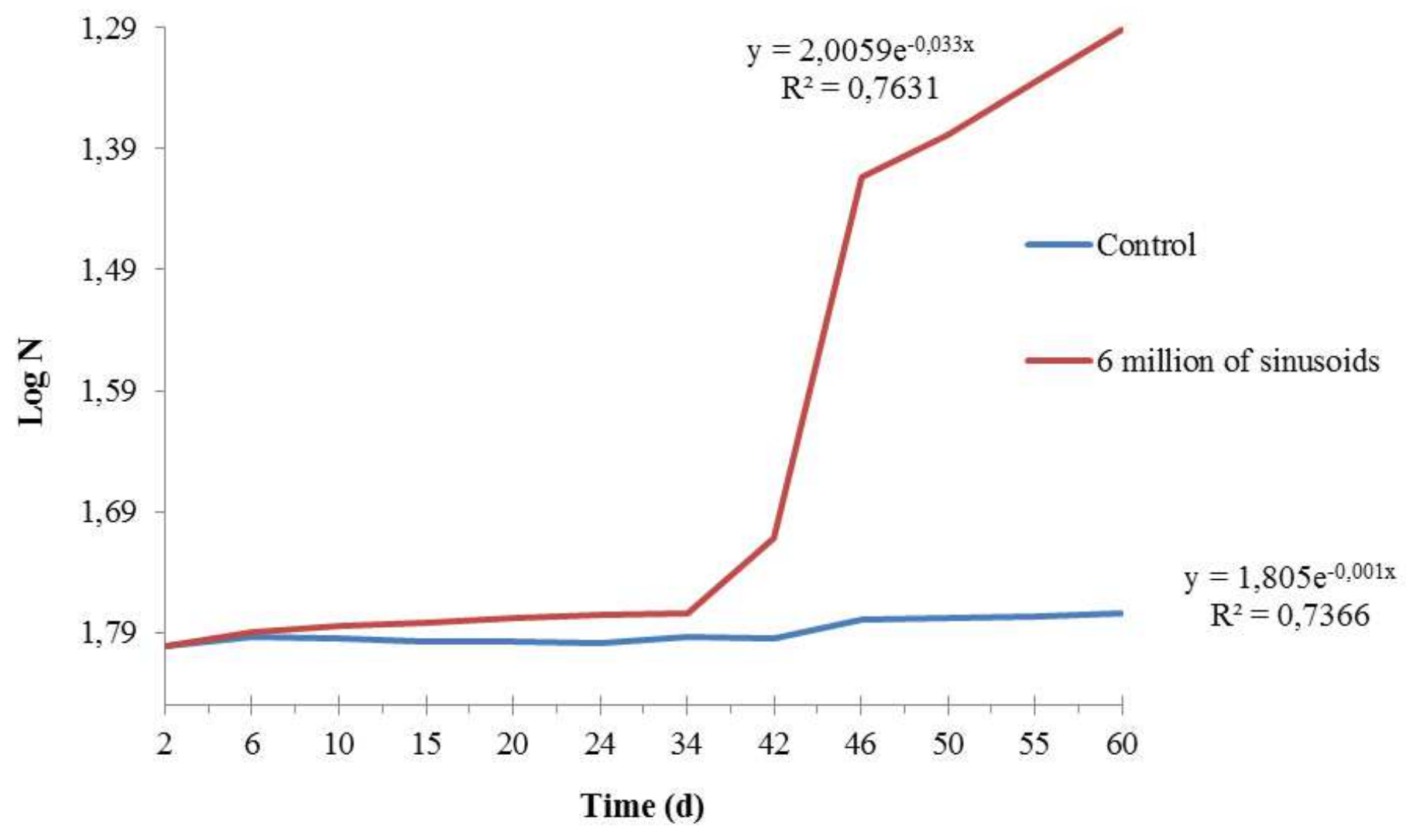

Figure 4

Log N vs Composting Time 


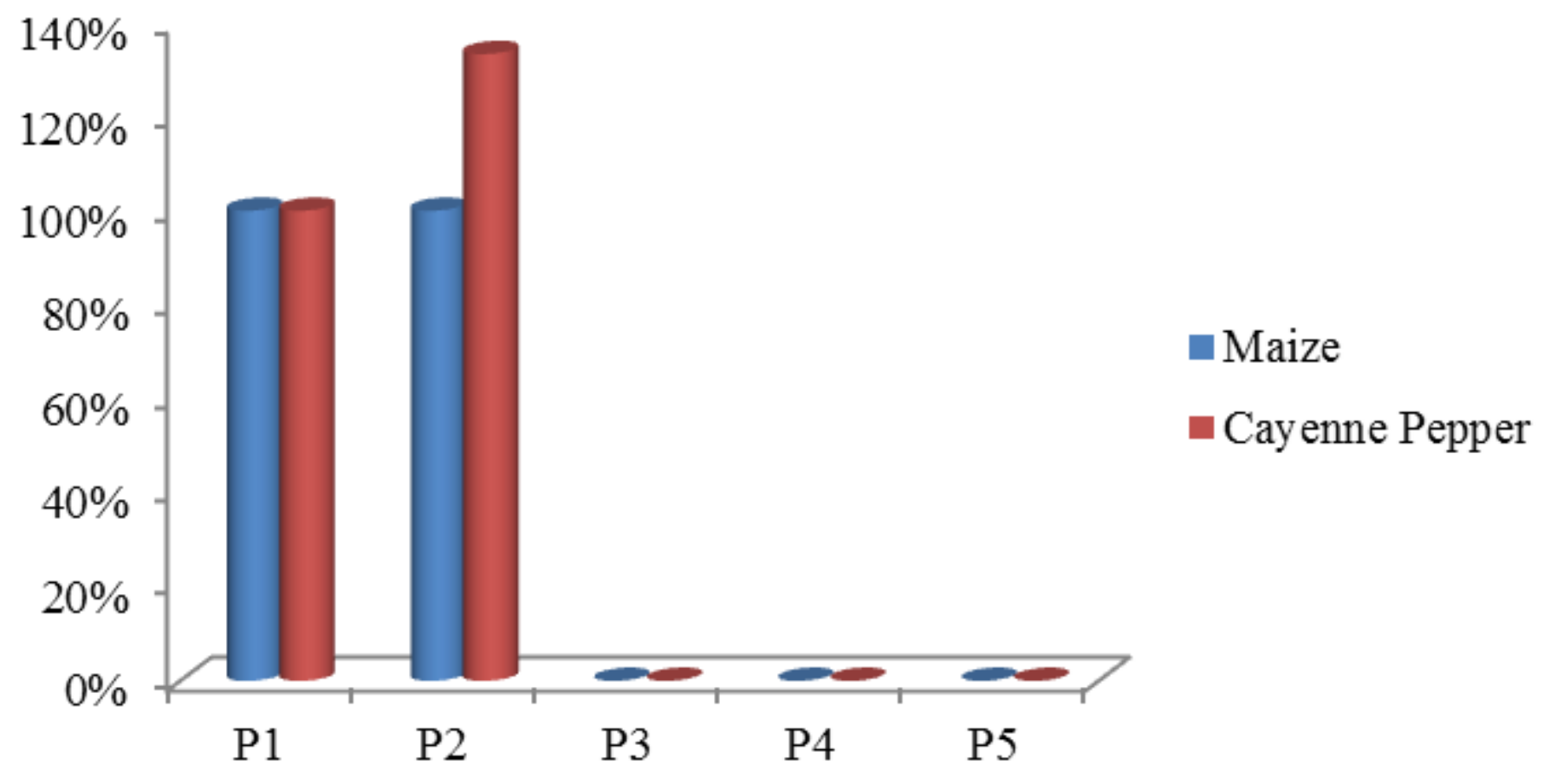

Figure 5

RSG for maize and cayenne pepper 